\title{
The Development of Physiological Growth Model of Beef Cattle in Semi Arid Environment to Meet Beef Demands for Tourism Sectors in East Nusa Tenggara
}

\author{
Maximilian M. J. Kapa*, \\ Department of Agribusiness, Faculty of Agriculture, Nusa Cendana University, Kupang, Indonesia
}

\begin{abstract}
This research was conducted at Raknamo and Tuatuka Villages, Amabi Oefeto Sub-District, Kupang Regency from September until November 2013. The aim of the research was to (1) build a growth model of beef cattle under extensive management system, and (2) formulate an adaptive model to estimate body weight of local beef cattle that will provide more accurate guessing and also give more benefit to farmer. Results of the research found that (1) beef cattle farming are viewed as an economic activity that uses of resources with low opportunity costs such as family labours and marginal land, (2) The model built showed a positive and very strongh relationship between body weight and girth for both male and female with determinant coefficients of 0.94 and 0.96 respectivelly. It means that body weight variable can be explained well by girth variable. The same condition applied to the relationship between body weight and age for male and female. Where the relationship between the two variables was also positive and and strong enough with determinant coefficients of 0.78 and 0.86 respectively.
\end{abstract}

Keywords: Model, beef cattle, girth, weight, age

\section{INTRODUCTION}

The development of tourism in Indonesia, especially in East Nusa Tenggara, needs the sufficient supplay of beef. The quantity and quality of beef is crucial to support restourant and traditional food business. In tourism sectors, the recent issues of sustainable livestock by involving local farmers were important. The demand of beef cattle not only merely meets the quantity, but also the quality of beef. There are also increasing issues related to livestock development. It is especially crucial because recent tourist was sensitive to food health and security. There also potential competition between beef daily consumption and hotel needs.

Livestock is an integral part of the farming systems in developing countries. Livestock is vital to the household economy in developing countries. The role of local farmer in beef cattle enterprise was important.The role of this sub sector has been recognized important in poverty reduction, especially in rural areas. In Indonesia, the statistical data record there is about 1.5 millions people are currently working in cattle farming. This activity is able to increase national beef production by $4.01 \%$ per year [1]. Many of these activities were found in rural area with interesting natural setting, such as rural in the

\footnotetext{
* Correspondence address:

Maximilian M.J. Kapa

Email : mmjkapa@gmail.com

Address : Dept. of Agribusiness, Faculy of Agriculture, Nusa Cendana University, Adisucipto, Penfui Kupang
}

perifer of forest, mountain, and coastal regions which endowed by spectacular landscapes. The cattle farm agribusinesssystem, however, can be integrated to the other rural economic subsystem such as rural tourism. It is partiulalry important in areas where agriculture and tourism are able to complement to build competitive rural tourism destination.

Meat consumption in Indonesia reach 5.5 gram per day, or equal to $2 \mathrm{~kg}$ per year [2]. Compared to other countries in the word, consumption pattern of Indonesian people were low. In Iran for instance, meat consumptions reach $10 \mathrm{~kg}$ per capita per year, while in Uruguai meat consumptions reach $60 \mathrm{~kg}$ per capita per year. With the number of total population about 200 million, Indonesia need more beef production.

The productivity of cattle in East Nusa Tenggara was stagnant. There are, however, decrease phenomena of cattle productivity. In the incrase of tourist arrivals which is flowed by increasing of beef consumption, the increasing of cattle productivity in East Nusa Tenggara becomes important. In 2013, number of tourist arrivals in East Nusa Tenggara reached 363.765 persons [3]. In responses of tourist increase, number of restaurant and hotels grows significantly. In 2013, number of restaurant was about 10.727 and number of hotels and other tourist accommodations were recorded about 285 buah [3]. Compared to the hotel and accommodation in 2009, the number of accommodation increased about $17.28 \%$ [4]. The above fact 
shows that beef demand will increase in the near future as a consequence of tourism growth in East Nusa Tenggara Province. This situation obligatelly depend of the beef farm productivity which is generated by local farmer.

The aims of the research were to build models of the cattle growth in extensive cattle farm systems based on the physiological characterits, encompasess age, girth, and body weight of cattle which is able to use to estimates cattle body weight. The second objective of the research was to draw models of which are adaptive to assist farmer to estimate cattle beef which is important in cattke farm agribusniness. These were addressed to support more efficient and more susutainable cattle beef agribusiness subsystems.

\section{MATERIALS AND METHODS \\ Study area}

The study was done in the semi arid area in West Timor. Two areas were sellected as study sites for field survey, namely Raknamo Village and Tuatuka Village in Amabi Oefeto Sub District, Kupang Regency, East Nusa Tenggara. The physical agroecosystem aspects indicate that these villages were classified into village with low to medium potential agriculculture productivity. Soils of these villages were dominated by lime sediments and corals lime stone.

Rainfall data from Metereological and Geophysical office in Kupang shows that rainfall occurs during November to March yearly. In some area however, experienced long dry periods with dry month of about 6-8 years. In such area, number of rainy days were calculated about 80-90 days with rain intensity was high to very high. Water as a crucial resource for agriculture was, therefore, limited in such area.

The temperature was relatively constant in a year. The maximum temperature was about $350 \mathrm{C}$ (recorded in October) while the minimum temperature was recorded about 23oC (in July). The high temperature was followed by high humidity (about 60-80\%). The highest humidity was recorded during December to March while the lowest humidity was found in July to September.

\section{Research Method}

Field work was conducted by interviewing 20 farmers. The interview questions focus on respondents social atributes and cattle physiological characteristics. The cattle morphological characterss was implemneted by measuring body of 134 heads of Bali cattle. It consisted of 65 males and 69 females. Some morphological characteristics which were measured encompases body weight $(\mathrm{kg})$, girth (cm) and cattle age (years). Cattle body weight was collected by measuring cattle using portable electronic balance RUDDWEIGH' Type KM-IE. Girth was measured using tape meter to 134 individual cattle. Data of cattle age was estimated following farmer estimation and also based on the cattle teeth examination by field extension worker.

\section{Data analysis}

The models of the relationship between age and body weight, and girth and body weight of male and female bali cattle were analized descriptevely using statistical package Data were analized using linear regression analysis which were transformed into logaritmic equation.

\section{RESULT AND DISCUSSION}

\section{Farm Management Profile}

The observed parameter of farmer respondents in this research encompasess ages of household head, education level, number of family members, farm size, number and kind of livestock. Based on the profile of 40 farmers, it is calculated that the average of farmer ages was about 41.3 years while the youngest farmer was 26 years and the oldest was about 50 years. The averages of famility member of farmer househould were about 6 persons. Number of family is ranging from 4-8 persons.

Based on the education level data, it is found that the majority of farmers have low education. There are no farmers finished high schools. About $90 \%$ have elementary education levels, $0.5 \%$ has completed junior high school education. The illiterate respondents were calculated about $0.5 \%$. This demography figure has been similar with many agricultural-based regions in Indonesia [5]. In the perpectives of age generation, it can be said that the farmer in study area were classified as productive labour. However, without adequate education levels, these will become the not productive labour. Education has significant impact to improve human resources in villages [6]. Government should be increasing the capacity and knowledge of farmer through numerous programs. Many of the respondents have been trained by local government in various farming activities, but it seems the programs not sufficient to increase 
farmer skill in agribusiness. Therefore, increasing eduation aspect is crucial [6].

All of the managed farm land in East Nusa Tenggara was dryland. Number of productive land and paddy field were limited. Some of the land was classified as homegardens. All of the respondens reported that they have private lands which are adequate to facilitate cattle farm extensive system. In this study, farmland size was used as an important indicator since land size is the important aspect in cattle farm, especially in extensive systems. The average size of land was 4.3 ha. About $50 \%$ of such land area was used in corn cultivation or other crops which was tolerant to dry environment.

Farmer manages land for numerous purposes, encompasess rainfed rice cultivation, dryland fields, and home gardens. The cultivated crop was diverse. Rice cultivation in rice field was done one time in year due to lack of water and poor water infrastructure. In home garden, kind of plant planted consists of medical plant, ornamental plants and corn. In the dryland field, farmer cultivates numerous secondary crops, such as corn, beans, cassava, pumpkin, kacang turis (local beans). In the forest garden, the common cultivated plants encompase coconut, areca nut, betel, banana, candlenut and other fuit plants. The crop profiles in both observed villages were summarized in Table 1.

Table 1. Crops production in research area

\begin{tabular}{llc}
\hline No. & \multicolumn{1}{c}{ Crops } & Production $\mathbf{( k g )}$ \\
\hline 1. & Corn & 752 \\
2. & Kacang Nasi (local bean) & 52.2 \\
3. & Cassava & 437 \\
4. & Peanuts & 21.4 \\
5 & Upland rice & 218 \\
\hline
\end{tabular}

The numbers in the table were generated from repondent information. There are several limitations the production measurement because farmers often neglected the quantity of agricultural product. This is because the orientation of farmer was to meet households need on food. The role of homegarden to provide basic family need in rural area has been reported important. People often cultivate numerous edible plants in home garden as an adaptive strategy to live in remote area [7].

\section{Livestock Management}

Diversity and number of livestock in both observed villages were numerous. The livestock varies from big animals (i.e. cattle) to small animals, such as goats, pigs and chicken. The average number of cattle was about 94 heads. The data of livestock were presented in Table 2.

Table 2. The livestock of farmer household in study area

\begin{tabular}{llc}
\hline No. & Live stock & Number (individual) \\
\hline 1. & Cattle & 94 \\
2. & Goats & 4 \\
3. & Pigs & 4 \\
4. & Chicken & 16 \\
\hline
\end{tabular}

Beef caltle in East Nusa Tenggara orriganaly was derived from Banteng (Bos Sondaicus). This cattle becomes famous and preferred by small farmer due to several reasons namely high fertility and has high adaptability to dry environments $[8,9]$. These cattle also preferred because it's high percentage of carcass. Bali cattle adapted well to the low quality of feed and therefore suitable in dry environment. These cattle are also can utilize low quality feed.

Based on the farmer experience in livestock management, about $59 \%$ of respondents have experience more than 15 years, while $41 \%$ has experience less than 15 years. Their experiences were varying from 5 to 14 years. This data show that cattle farming are not the new activity to the respondent in East Nusa Tenggara.

\section{Beef Cattle Production Systems}

Based on the field observation, there four dominat aspect of the background from beef cattle farming. The main reson for beef cattle farming is relted to the direct household revenue. Catlle is the important savings systems which area able to withdrawn in anytime farmer need cash money. Beef cattle farming is the main economic activity, especially for farmier without owned lands. Beef cattle farmeing is also done to meet social and cultural needs for beef. Socially, farmer with large numner of catlle has special status in community.

Based on the field observation, there are two systems for beef production, namely extensive systems and fattening systems. The majority of production, however, is extensive system. This system refers to the cattle farming in large area with abundance grasess.

\section{Beef Cattle Management}

This study shows that there are two management of Beef cattle management. This management was influenced by several factors, namely food stock sources, number of cattle, and available of labour. The limitaton of grass lead 
farmer to release cattle in savanna. It is especially faound in farmer community with large number of cattle, of farmer with large some number of cattle. The grazing area can be very large to increase opportunities of cattle to found fresh and edible grasesses.

Economically, it is important to reduce cost. For farmer with few cattle, there are opportunities for semi intensive systems. During the rainy season, grass was abundan-ce. There are opportunities to shepherded cattle in farmlands or grassland near settlement. Gra-zing area can be reach 4-6 km from house $[10,11]$.

\section{Labours}

Labours is important input aspect in livestock production systems. Mainly in the dry season where fodder, grass and other feeds are very limited, the owner have to spend more time to shepperd their cattle and to find other source of fodder. As a comparison, the workdays of farmer during rainy season was about 107.142 mandays, while in the dry season it was calculated about 240 man-days.

\section{Cattle Physiological Models Assessment in Semi Arid Areas}

Previous research shows that hearth girth is the valuable variable to predict cattle body weight [12]. Therefore the reasons to measure relationship between girth and body weight was to generate equation model relationship between two mentioned variable in Bali cattle under extensive farm system in dry land in West Timor, East Nusa Tenggara. This equation models was expected to guide field extension worker to assist farmer in cattle body weight estimation.

Algoritmic model was used to tranform two variables which were representing the typical relationship of both linear curves. The regression equation of the relationship between girth and body weight of the Bali cattle was presented in Table 3.

Based on the regression equation above, it is clear that girth has significant relationship to the value of body weight variable $\left(\alpha_{0,01}\right)$. This means that increase of girth contributes significantly to body weight. The regression coefficient value of
2.873 shows that increase of 1 units of girth contributes significantly in the increasing of 2.873 unit weight of male cattle. Similary occurs in female cattle. Increase of 1 unit of girth will contributes about 2.597 unit increase of body weight.

The determinant coefficient value $\left(R^{2}\right)$ of male and female cattle was 0.94 and 0.96 respectively. It shows the variation of cattle body weight can be described by the girth variable. Therefore the models can be used to assess both female and male bali cattle body weight. The $F$ test support that body weight variable was significantly determined by girth variable.

\section{The Relationsip of Age and Body Weight}

Teoritically, the relationship between individual ages and body weigh was clear. Ideally, increase of individual age will be significantly followed by increase of body weight. The production function teory argues that the increase of individual age will be followed by increasing body weight. In the beginning, the increase of body weight relatively fast and growth slowly. In some periods, age continuous but body weight stagnant. In some case, however, body weight decrease. This function following economic law called: The low of diminishing return. Result of the regression of the relationship between ages and body weight was summarized in Table 4.

Table 4 indicates that all of the regression coefiicients of both male and female cattle have positive values. These calculations show significant relationship $\left(\alpha_{0,01}\right)$ between two variables. In the first model, the regression coeficient has positive value $(0.432)$, it means that if cattle age increase by one unit, it will be foolowed by icreasing of cattle body weight about 0.432 units.

The similar calculation was found in male Bali cattle. Increase of one unit level of ages contributes to the increase of cattle body weight about 0.46 units. The determinat coefficient $\left(R^{2}\right)$ of both sex shows that the fluctuation of decrease and increase of body weight about $70 \%$ can be explained by age variables, while $86 \%$ of body weight variable can be explained by independent variable (age).

Table 3. The regression equation between hearth girth and body weight of the Bali Timor cattle in extensive system of the semi arid environments

\begin{tabular}{lccccc}
\hline Sex & Regresion equation & $\mathbf{n}$ & $\mathbf{R}^{\mathbf{2}}$ & $\mathbf{S}$ & $\mathbf{F}$ \\
\hline Female & LogBW $=-8.421+2.873 \log \mathrm{G}$ & 69 & 0.94 & 0.05 & $5495.80^{* *}$ \\
Male & LogBW $=-8.503+2.579 \log \mathrm{G}$ & 65 & 0.96 & 0.04 & $8491.06^{* *}$ \\
\hline \multicolumn{5}{c}{ Notes: $^{* *}$ Significant in level 99\%. BW $=$ body weight, G = Girth }
\end{tabular}


Physiological Growth Model of Beef Cattle to Meet Beef Demad for Tourism Sector in

East Nusa Tenggara (Kapa)

Table 4. The regression equation between ages and body weight of the Bali cattle in extensive system of the semi arid environments

\begin{tabular}{lccccc}
\hline Sex & Regression & $\mathbf{n}$ & $\mathbf{R}^{\mathbf{2}}$ & $\mathbf{S}$ & $\mathbf{F}$ \\
\hline Female & Log BW=3.722+0.432 log AG & 69 & 0.70 & 0.05 & $4353.80^{* *}$ \\
Male & Log BW= 3.587+0.46 log AG & 65 & 0.86 & 0.04 & $4375.12^{* *}$ \\
\hline \multicolumn{5}{c}{ Notes: ** Significant in level 99\%. BW = body weight, AG = Ages }
\end{tabular}

The limits of this study related to the limited number of cattle samples and ages estimation by farmer. However, using extrapolation approach it is possible to assess the daily increase of body weight of both male and female cattle. Extrapolation Result of the above regression equation was given in Table 5 .

Table 5. Estimation of body weight of Bali Cattle in extensive systems

\begin{tabular}{ccc}
\hline \multirow{2}{*}{ Age (Months) } & \multicolumn{2}{c}{$\begin{array}{c}\text { Average of body weight increase } \\
\text { (g.day }{ }^{-1} \text { ) }\end{array}$} \\
\cline { 2 - 3 } & Male & Female \\
\hline $0-3$ & 593 & 560 \\
$4-6$ & 275 & 209 \\
$7-9$ & 198 & 143 \\
$10-12$ & 165 & 121 \\
$13-18$ & 132 & 93 \\
$19-24$ & 104 & 71 \\
$25-30$ & 99 & 66 \\
$31-36$ & 88 & 49 \\
$37-48$ & 78 & 47 \\
$49-60$ & 69 & 41 \\
\hline
\end{tabular}

Based on the data in Table 5, it is clear that male and female catlle with ages under 10 months has similar growth trend. After 10 months of ages, the male cattle tend to grow faster than female cattle. Data above also explain that daily gain for both male and female becomes low and when they reach 5 years of age their daily gain will drop below $0.5 \mathrm{~kg}$. This is the common condition in rural area, especially in extensive system cattle farming.

Physiological aspect of animals is important aspect in production management. In the recent fast growing of tourism, the production of cattle beef was important. Farmer has important contribution to mainatain and increase beef cattle production. The important of this finding is able to help livestock owners to estimate their cattle body weight as fas as the age of the animal is available.

\section{CONCLUSION}

The beef farm in Kupang regency, East Nusa Tenggarara province, was implemented in traditional ways with low capital and labours. In order to decrease farm cost, the family member was involved in livestoct systems and management. Lives toct was done in marginalized land with limiting reasources. Among the local people, numer of beef which are owned by hoes hold family was viewed family capital, social status, and a food buffer in failure crop harvest.

This research shows that there are close relationship among girth and cattle body weight. This means girth data is able to use to estimate cattle body weight, especially in remotes area where balance instrument difficult to find. There are also close relationship among ages and cattle body weight. Age varable can be used to estimates cattle body weight. This research support previous research that states extensive cattle enterprise in semi arid area has low body weight gain. There are however, opportunities to increase body weight through proper feeding system management.

\section{REFERENCES}

[1] Kusnadi, U. K. 2008. Inovasi teknologi peternakan dalam sistem integrasi tanaman -ternak untuk menunjang swasembada daging sapi. Jurnal Pengembangan Inovasi Pertanian 1(3), 189-205.

[2] Widianarko, B. 2013. Mengapa kita mesti makan daging sapi (impor)? Surya Merdeka Daily Newspaper. March $1^{\text {st }}$.

[3] BPS NTT. 2010. Nusa Tenggara Timur dalam Angka 2010. Center of Statistic East Nusa Tenggara. Kupang.

[4] BPS NTT. 2014. Nusa Tenggara Timur dalam Angka 2014. Center of Statistic East Nusa Tenggara. Kupang.

[5] Grootaert, C. 1999. Social Capital, household welfare, and poverty in Indonesia. World Bank Policy Research paper 2148.

[6] Davis K., N. Konya, E. Kato, E. McKonnen, D. A. Odendom, R. Milirio, and J. Nkuba. 2012. Impact of farmer field schools on agricultural productivity and poverty in East Africa. World Development 40(2), 402-413.

[7] Rahu, A. A., K. Hidayat, M. Ariyadi, and L. Hakim. 2014. Menegement of Kaleka (traditional gardens) in Dayak community in Kapuas, Central Kalimantan. International 
Journal of Sciences and Research 3(3), 205210.

[8] Pane, 1990. Upaya Peningkatan Mutu Genetik Sapi Bali di P3 Bali. Proceeding Seminar Nasional Sapi Bali. Fapet Universitas Udayana. Denpasar Bali.

[9] Masudana, 1990. Upaya Pemuliaan dan Pelestarian Sapi Bali untuk Menunjang Pembangunan Peternakan Secara Nasional. Proceeding Seminar Nasional Sapi Bali. Fapet Universitas Udayana. Denpasar Bali.

[10] Kapa, M. M. J. 2007. Produktivitas usahatani dalam sistem pertanian terpadu: studi kasus di Kecamatan Amarasi, Kabupaten Kupang, Nusa Tenggara Timur. In: Integrated Rural Development in East Nusa Tenggara, Indonesia. ACIAR Proceedings (126).

[11] Kapa, M. M. J. 1994. A comparison of cattle management systems in Kupang District, East Nusa Tenggara. Indonesia. Master Thesis. University of Melbourne.

[12] Perkins, J. and A. Semali. 1992. Economic evaluation of draught animals. In: Teleni, E., R. S. F. Campbell, and D. Hoffman (Eds). Draught Animal Systems Management: An Indonesian Study. ACIAR. Canberra. 